\title{
Pengaruh Kompetensi Aparat Pengelola Dana Desa, Komitmen Organisasi Pemerintah Desa, dan Partisipasi Masyarakat Terhadap Akuntabilitas Pengelolaan Dana Desa Di Kabupaten Gorontalo
}

\author{
SARIFUDIN MADA ${ }^{1}$, LINTJE KALANGI ${ }^{2}$, HENDRIK GAMALIEL ${ }^{3}$
}

\author{
${ }^{1,2,3}$ Program Magister Akuntansi, Fakultas Ekonomi dan Bisnis Universitas Sam Ratulangi \\ email: 15062103055@student.unsrat.ac.id ${ }^{1}$, lintjekalangi@yahoo.com² ${ }^{2}$,hendrik_gamaliel@unsrat.ac.id ${ }^{3}$
}

\begin{abstract}
The accountability of village fund management has become a demand for local government. The existence of this demand results from the implementation of Law No. 6 of 2014 on the Village. The management of village funds in Gorontalo Regency is still far from the expectations. Problems emerging from the accountability of village fund management are related to the competence of village fund management officers, the commitment of village government organizations, and community participation. This research aims to know and analyze the influence of competence of village fund management officer, commitment of village government organization, and public participation to accountability of village fund management in Gorontalo Regency. This is a quantitative research study and data were collected by surveys or questionnaires. Population and sample are village fund management officers in Gorontalo Regency with 120 respondents. The hypothesis was tested by multiple linear regression analysis with SPSS application. The findings show that: (1). The competence of village fund management officers has a positive and significant impact on the accountability of village fund management; (2). The commitment of village government organizations has a positive and significant impact on the accountability of village fund management; (3). Community participation has a positive and significant impact on the accountability of village fund management. The coefficient of determination is 0.751 . This shows that the influence of independent variables namely: the competence of the village fund management officer, the commitment of the village government organization, and the participation of the society, towards the dependent variable (the accountability of village fund management) explained by the equation model in this research is $75.10 \%$. While the rest of $24.90 \%$ is explained by other factors which are not included in this model. The implications of this study are to encourage the accountability of village fund management through the increased competence of village fund management officers, village government organizational commitment, and community participation.
\end{abstract}

Keywords: Competence of village fund management officers, Commitment of village government organization, Community participation, accountability of village fund management.

\begin{abstract}
Abstrak. Akuntabilitas pengelolaan dana desa sudah menjadi sebuah tuntutan bagi pemerintah desa. Adanya tuntutan ini sebagai akibat implementasi Undang-Undang Nomor 6 Tahun 2014 tentang Desa. Pengelolaan dana desa di Kabupaten Gorontalo masih jauh dari harapan. Masalah yang timbul terkait akuntabilitas pengelolaan dana desa berkaitan dengan kompetensi aparat pengelola dana desa, komitmen organisasi pemerintah desa, dan partisipasi masyarakat. Penelitian ini bertujuan untuk mengetahui dan menganalisis pengaruh kompetensi aparat pengelola dana desa, komitmen organisasi pemerintah desa, dan partisipasi masyarakat terhadap akuntabilitas pengelolaan dana desa di Kabupaten Gorontalo. Jenis penelitian ini adalah penelitian kuantitatif metode survey. Populasi dan sampel adalah aparat pengelola dana desa di Kabupaten Gorontalo sejumlah 120 responden. Pengumpulan data menggunakan kusioner. Pengujian hipotesis menggunakan analisis regresi linier berganda dengan aplikasi SPSS. Hasil penelitian menunjukkan bahwa: (1). Kompetensi aparat pengelola dana desa berpengaruh positif dan signifikan terhadap akuntabilitas pengelolaan dana desa; (2). Komitmen organisasi pemerintah desa berpengaruh positif dan signifikan terhadap akuntabilitas pengelolaan dana desa; (3). Partisipasi masyarakat berpengaruh positif dan signifikan terhadap akuntabilitas pengelolaan dana desa. Nilai koefisien determinasi adalah 0,751 . Hal ini menunjukkan bahwa besarnya pengaruh variabel independen, yaitu kompetensi aparat pengelola dana desa, komitmen organisasi pemerintah desa, dan partisipasi masyarakat terhadap variabel dependen yaitu akuntabilitas pengelolaan dana desa yang diterangkan oleh model persamaan dalam penelitian ini adalah sebesar $75,10 \%$. Sedangkan sisanya sebesar $24,90 \%$ dijelaskan oleh faktor-faktor lain yang tidak dimasukkan dalam model ini. Implikasi temuan penelitian ini adalah untuk mendorong pengelolaan dana desa yang akuntabel melalui peningkatan kompetensi aparat pengelola dana desa, komitmen organisasi pemerintah desa, dan partisipasi masyarakat.
\end{abstract}

Kata kunci: Kompetensi aparat pengelola dana desa, komitmen organisasi pemerintah desa, partisipasi masyarakat, akuntabilitas pengelolaan dana desa. 


\section{Pendahuluan}

Desentralisasi adalah wewenang pemerintahan yang diberikan pusat kepada daerah (Bicu, 2013:120). Desentralisasi terdiri dari berbagai aspek yaitu desentralisasi politik (demokrasi), desentralisasi administratif (dekonsentrasi), dan desentralisasi fiskal (Francis dan James, 2003:326, Agrawal dan Ribot, 1999:3). Desentralisasi bertujuan agar pemerintah dapat lebih meningkatkan efisiensi serta efektivitas fungsi-fungsi pelayanannya kepada seluruh lapisan masyarakat (Nadir, 2013). Hal ini disebabkan adanya desentralisasi memberikan ruang gerak bagi pemerintah di tingkat bawah untuk mengurus wilayahnya sendiri sesuai wewenang dan tanggung jawab yang dilimpahkan kepadanya. Dengan demikian, tugas dan tanggung jawab pemerintah pusat kepada seluruh lapisan masyarakat di tingkat bawah dapat dilaksanakan. Di Indonesia, salah satu bentuk desentralisasi yang sedang dilaksanakan adalah pelimpahan kewenangan pemerintah pusat kepada daerah dan daerah kepada desa. Kewenangan kepada desa ini dilegitimasi dengan diterbitkannya berbagai regulasi. Kebijakan pemerintah melimpahkan kewenangan kepada desa secara otonom adalah untuk meletakkan pondasi pembangunan dimulai dari tingkat desa. Ini jelas terlihat dalam Rencana Pembangunan Jangka Menengah Nasional (RPJMN) 2015-2019 yang mengamanatkan untuk membangun Indonesia dari pinggiran dan memperkuat daerah dan desa. Hal ini dimaksudkan untuk menjawab persoalan kemiskinan dan kerentanan akibat dari ketimpangan pembangunan yang telah dilakukan (Kementerian Desa, Pembangunan Daerah Tertinggal dan Transmigrasi RI, 2015).

Secara Nasional, pemerintah telah mengalokasikan anggaran dana desa dengan nilai yang cukup fantastis untuk sebuah program/kebijakan yang baru. Berdasarkan data pada Kementerian Keuangan RI (Nota Keuangan), jumlah dana desa yang telah dianggarkan oleh pemerintah dalam 3 (tiga) tahun terakhir adalah sebesar Rp.127,75 Triliun. Dengan rincian sebagai berikut: pada tahun 2015 sebesar Rp.20,77 Triliun, tahun 2016 sebesar Rp.46,98 Triliun, dan tahun 2017 sebesar Rp.60 Triliun. Momentum dana desa diharapkan dapat membiayai penyelenggaraan pemerintahan, pelaksanaan pembangunan, pembinaan kemasyarakatan, dan pemberdayaan masyarakat. Secara khusus dana desa diharapkan dapat mengurangi jumlah desa tertinggal sampai 5.000 desa, dan meningkatkan jumlah desa mandiri sedikitnya 2.000 desa pada tahun 2019. Fakta menunjukkan bahwa pada tahun 2015 jumlah desa mandiri sebanyak 3.608 dari 73.709 atau 4,89\% dan jumlah desa tertinggal sebanyak 33.592 dari 73.709 atau 45,57\%. (Kementerian Desa, Pembangunan Daerah Tertinggal dan Transmigrasi RI, 2015).

Berdasarkan evaluasi penyaluran dan penggunaan dana desa tahun 2015, terdapat keterlambatan dan rendahnya penyaluran dana desa dari kabupaten/kota ke desa. Dalam hal penggunaan dana desa, masih terdapat penggunaan dana desa diluar prioritas penggunaan, pekerjaan konstruksi dilakukan seluruhnya oleh pihak ketiga, hasil pengadaan tidak dapat digunakan/dimanfaatkan, pengeluaran dana desa tidak didukung dengan bukti yang memadai, dan kelebihan perhitungan volume RAB (Kementerian Keuangan RI, 2016:19). Hasil evaluasi penggunaan dana desa semester satu tahun 2016 masih mengalami permasalahan. Permasalahan tersebut antara lain: penggunaan dana desa diluar bidang prioritas, pengeluaran dana desa tidak didukung dengan bukti yang memadai, pekerjaan konstruksi dilakukan seluruhnya oleh pihak ketiga/ penyedia jasa, kelebihan pembayaran, pemungutan dan penyetoran pajak tidak sesuai, dana disimpan bukan di RKD, dan pengeluaran diluar APBDesa (Kementerian Keuangan RI, 2016:19).

Beberapa permasalahan yang terjadi antara lain: keterlambatan penyampaian laporan, belum berkesesuaian laporan pertanggungjawaban yang dibuat, penggunaan dana desa melewati batas cut off 31 Desember tahun anggaran berkenaan, belum tertibnya administrasi keuangan, meningkatnya temuan desa, keterlambatan dalam penyusunan anggaran, dan belum optimalnya penyerapan anggaran. Dengan demikian penulis menduga bahwa permasalahan akuntabilitas pengelolaan dana desa di Kabupaten Gorontalo diakibatkan oleh beberapa faktor antara lain kompetensi aparat pengelola dana desa yang belum memadai, lemahnya komitmen organisasi pemerintah desa dan kurangnya partisipasi masyarakat (Subroto, 2009, Anwar dan Jatmiko, 2012, Karimah, 2014, Fajri, 2015, Riyanto, 2015, Dewi, 2016, Ferina, 2016, Aziz, 2016, Mamelo, 2016, dan Makalalag, 2017).

Berdasarkan uraian latar belakang tersebut diatas, maka rumusan masalah dapat dinyatakan sebagai berikut:

1) Apakah kompetensi aparat pengelola dana desa berpengaruh terhadap akuntabilitas pengelolaan dana desa?

2) Apakah komitmen organisasi pemerintah desa berpengaruh terhadap akuntabilitas pengelolaan dana desa?

3) Apakah partisipasi masyarakat berpengaruh terhadap akuntabilitas pengelolaan dana desa? 
Tujuan yang hendak dicapai dalam penelitian ini adalah untuk menguji secara empiris pengaruh kompetensi aparat pengelola dana desa, komitmen organisasi pemerintah desa, dan partisipasi masyarakat terhadap akuntabilitas pengelolaan dana desa di Kabupaten Gorontalo.

\section{Gambar 1. Kerangka Konseptual}

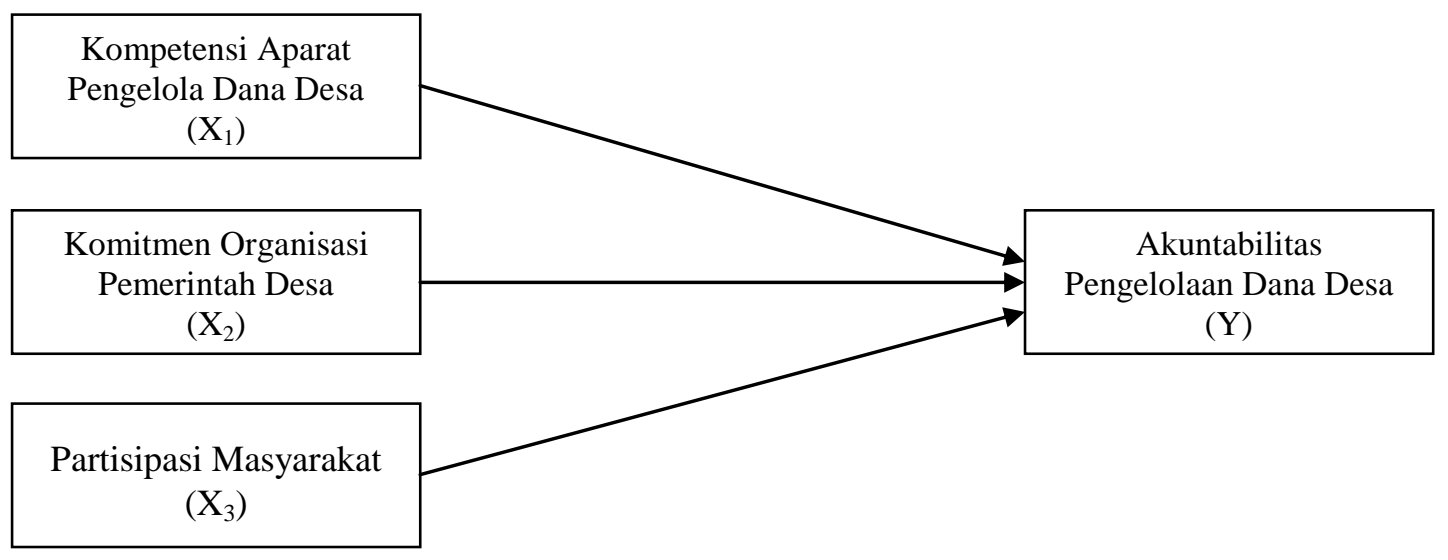

Berdasarkan landasan teori dan hasil-hasil penelitian terdahulu, maka hipotesis dalam penelitian ini adalah sebagai berikut:

1. Pengaruh Kompetensi Aparat Pengelola Dana Desa terhadap Akuntabilitas Pengelolaan Dana Desa.

Kompetensi merupakan faktor yang dapat mempengaruhi akuntabilitas. Untuk meningkatkan akuntabilitas diperlukan adanya kompetensi (Frink dan Klimoski, 2004:14). Pendapat tersebut sejalan dengan beberapa penelitian. Penelitian tersebut pernah dilakukan oleh Subroto (2009), Irma (2015), Fajri (2015), Aziz (2016), Ferina (2016), Dewi (2016), dan Makalalag (2017). Hasil penelitian menyatakan bahwa kompetensi sumber daya manusia merupakan salah satu faktor yang mempengaruhi akuntabilitas pengelolaan dana desa. Perumusan hipotesis adalah sebagai berikut:

$\mathrm{H}_{1}$ : Kompetensi aparat pengelola dana desa berpengaruh positif terhadap akuntabilitas pengelolaan dana desa.

\section{Pengaruh Komitmen Organisasi Pemerintah Desa terhadap Akuntabilitas Pengelolaan Dana Desa.}

Komitmen organisasi berkaitan erat dengan akuntabilitas. Beberapa pakar yang mengemukakan bahwa komitmen organisasi merupakan faktor yang mempengaruhi akuntabilitas adalah: Cavoukian et al (2010:408), bahwa komitmen organisasi diperlukan dalam akuntabilitas. Komitmen organisasi merupakan salah satu elemen penting dalam akuntabilitas. Behnam dan MacLean (2011:49), bahwa dukungan terhadap komitmen organisasi mempengaruhi standar akuntabilitas. Roberts (2002:664), bahwa komitmen organisasi terhadap publik diilustrasikan memberikan manfaat terhadap sistem akuntabilitas. Brown dan Moore (2001:20), bahwa perubahan besar dapat terjadi pada akuntabilitas sebuah organisasi melalui komitmen untuk bekerja keras daripada lebih memperhatikan konstituen. Perumusan hipotesis adalah sebagai berikut:

$\mathrm{H}_{2}$ : Komitmen organisasi pemerintah desa berpengaruh positif terhadap akuntabilitas pengelolaan dana desa.

\section{Pengaruh Partisipasi Masyarakat terhadap Akuntabilitas Pengelolaan Dana Desa.}

Menurut Crook dan Sverrisson dalam Devas dan Grant (2003:309) Akuntabilitas dapat diperkuat melalui peningkatan partisipasi masyarakat. Sebagai kunci untuk meningkatkan responsivitas pemerintah daerah terhadap masyarakat miskin, dan untuk membuat pembangunan lebih berpihak pada orang miskin. Sebagai mekanisme dalam pertanggungjawaban, partisipasi dilakukan mulai dari evaluasi sampai pelaporan (Ebrahim, 2003:818). Seperti di Los Angeles, partisipasi merupakan cara untuk meningkatkan akuntabilitas sebagai tanggapan yang muncul terhadap tingginya ketidakpercayaan masyarakat terhadap pemerintah. Banyak warga yang menyalahkan pejabat dalam pengambilan keputusan (Kim dan Schachter, 2013:462). Perumusan hipotesis adalah sebagai berikut:

$\mathrm{H}_{3}$ : Partisipasi masyarakat berpengaruh positif terhadap akuntabilitas pengelolaan dana desa. 


\section{Metode Penelitian}

Jenis penelitian yang dilakukan adalah jenis penelitian kuantitatif metode survey. Sumber data yang digunakan dalam penelitian ini adalah data primer, yaitu data yang diperoleh menggunakan instrumen kuesioner. Populasi dari penelitian ini adalah pengelola dana desa di Kabupaten Gorontalo, terdiri atas: Kepala desa, Sekretaris desa, Bendahara, dan Unsur Kaur. Teknik pengambilan sampel menggunakan Proportionate Stratified Random Sampling. Strata sampling adalah desa pesisir pantai, desa dataran rendah, dan desa dataran tinggi/pegunungan. Total sampel dalam penelitian ini adalah seratus dua puluh aparat pengelola dana desa.

Tabel 1

Konstruk, Dimensi dan Indikator Variabel

\begin{tabular}{|c|c|c|}
\hline Konstruk & Dimensi & Indikator \\
\hline \multirow{3}{*}{$\begin{array}{l}\text { Kompetensi Aparat } \\
\text { Pengelola Dana Desa } \\
\text { (Edison } \text { et al, 2016) }\end{array}$} & $\begin{array}{l}\text { Pengetahuan } \\
\text { (Knowledge) }\end{array}$ & $\begin{array}{l}\text { - Pengetahuan } \\
\text { - } \text { Kemampuan untuk meningkatkan pengetahuan }\end{array}$ \\
\hline & Kemampuan (skill) & $\begin{array}{ll}- & \text { Keahlian teknis } \\
\text { - } & \text { Kemampuan mencari solusi } \\
\end{array}$ \\
\hline & Sikap (attitude) & $\begin{array}{ll}- & \text { Inisiatif dalam bekerja } \\
\text { - } & \text { Keramahan dan kesopanan }\end{array}$ \\
\hline \multirow{3}{*}{$\begin{array}{l}\text { Komitmen Organisasi } \\
\text { Pemerintah Desa } \\
\text { (Porter } \text { et al, 1974) }\end{array}$} & Afektif & $\begin{array}{ll}\text { - } & \text { Keyakinan terhadap tujuan organisasi } \\
\text { - } & \text { Perasaan memiliki organisasi }\end{array}$ \\
\hline & Keberlanjutan & $\begin{array}{l}\text { - Mempertahankan keanggotaan organisasi } \\
\text { - } \text { Kesetiaan dalam organisasi }\end{array}$ \\
\hline & Normatif & $\begin{array}{l}\text { Kesediaan mengerahkan upaya atas nama } \\
\text { organisasi }\end{array}$ \\
\hline \multirow{3}{*}{$\begin{array}{l}\text { Partisipasi Masyarakat } \\
\text { (Heller et al, 1984, dan } \\
\text { Sujarweni (2015), }\end{array}$} & $\begin{array}{l}\text { Pengambilan } \\
\text { keputusan }\end{array}$ & $\begin{array}{l}\text { - Keterlibatan dalam pengambilan keputusan } \\
\text { program-program desa }\end{array}$ \\
\hline & $\begin{array}{l}\text { Penyusunan } \\
\text { anggaran }\end{array}$ & $\begin{array}{ll}\text { - } & \text { Mengusulkan rencana anggaran } \\
\text { - } & \text { Terlibat dalam rapat paripurna }\end{array}$ \\
\hline & $\begin{array}{l}\text { Pelaksanaan } \\
\text { anggaran }\end{array}$ & $\begin{array}{ll}\text { - } & \text { Terlibat mengawasi dan melaporkan } \\
\text { - } & \text { Memberikan penilaian pelaksanaan anggaran } \\
\text { - } & \text { Memberikan penghargaan }\end{array}$ \\
\hline \multirow{2}{*}{$\begin{array}{l}\text { Akuntabilitas } \\
\text { Pengelolaan Dana Desa } \\
\text { (Mahmudi, 2011) }\end{array}$} & $\begin{array}{l}\text { Kejujuran dan } \\
\text { Hukum }\end{array}$ & $\begin{array}{l}\text { - Kejujuran dan keterbukaan informasi } \\
\text { - Kepatuhan dalam pelaporan }\end{array}$ \\
\hline & Proses & $\begin{array}{ll}\text { - } & \text { Kesesuaian prosedur } \\
\text { - } & \text { Kecukupan informasi } \\
\text { - } & \text { Ketepatan penyampaian laporan }\end{array}$ \\
\hline
\end{tabular}

Teknik analisis data menggunakan uji asumsi normalitas dan uji asumsi klasik multikolinieritas dan uji heteroskedastisitas, serta uji hipotesis yaitu uji statistik t. Model analisis regresi linier berganda sebagai berikut:

$\mathrm{Y}_{\mathrm{i}} \quad=\beta_{0}+\beta_{1} \mathrm{X}_{1 \mathrm{i}}+\beta_{2} \mathrm{X}_{2 \mathrm{i}}+\beta_{3} \mathrm{X}_{3 \mathrm{i}}+e$

Dimana:

$\mathrm{Y}_{\mathrm{i}} \quad=$ Akuntabilitas pengelolaan dana desa

$\beta_{0} \quad=$ Koefisien regresi

$\beta_{1} X_{1 \mathrm{i}} \quad=$ Kompetensi aparat pengelola dana desa

$\beta_{2} X_{2 i} \quad=$ Komitmen organisasi pemerintah desa

$\beta_{3} X_{3 i} \quad=$ Partisipasi masyarakat

$e=$ Variabel gangguan/kesalahan (disturbancelerror terms) 


\section{Hasil Penelitian dan Pembahasan \\ Uji Statistik Deskriptif.}

Tabel 2

Descriptive Statistics

\begin{tabular}{|l|c|c|c|c|c|}
\hline & Mean & Std. Deviation & Max & Min & $\mathrm{N}$ \\
\hline Akuntabilitas Pengelolaan Dana Desa $(\mathrm{Y})$ & 3,9467 & 0,59266 & 5,00 & 2,20 & 120 \\
Kompetensi Aparat Pengelola Dana Desa $\left(\mathrm{X}_{1}\right)$ & 4,0708 & 0,67468 & 5,00 & 2,00 & 120 \\
Komitmen Organisasi Pemerintah Desa $\left(\mathrm{X}_{2}\right)$ & 3,8283 & 0,85996 & 5,00 & 2,00 & 120 \\
Partisipasi Masyarakat $\left(\mathrm{X}_{3}\right)$ & 3,8550 & 0,86275 & 4,80 & 2,00 & 120 \\
\hline
\end{tabular}

Sumber: Hasil olahan SPSS, 2017

Uji Normalitas. Hasil pengujian menunjukkan nilai koefisien Kolmogorov-Smirnov Z sebesar 1,112 dengan tingkat signifikansi sebesar 0,168 . Nilai signifikansi ini lebih besar dari $\alpha 0,05$ $(0,168>0,05)$. Hal ini menunjukkan bahwa data dalam variabel penelitian ini terdistribusi secara normal. Dengan demikian data dalam variabel ini baik dan layak digunakan dalam penelitian.

Tabel 3

Hasil Uji Normalitas

\begin{tabular}{|ll|r|}
\hline & & Unstandardized Residual \\
\hline $\mathrm{N}$ & & 120 \\
Normal Parameters & \\
& Mean & 0 \\
Most Extreme Differences & Std. Deviation & 0,29557619 \\
& Absolute & 0,102 \\
& Positive & 0,102 \\
& Negative & $-0,086$ \\
Kolmogorov-Smirnov Z & & 1,112 \\
Asymp. Sig. (2-tailed) & & 0,168 \\
\hline
\end{tabular}

Sumber: Hasil olahan SPSS, 2017

Uji multikolinieritas. Nilai VIF dari semua variabel independen berada antara 1-10. Hal ini menunjukkan bahwa antara variabel independen tidak terjadi korelasi yang kuat. Ini berarti bahwa tidak terdapat masalah kemiripan antar variabel independen atau tidak terjadi masalah multikolinieritas dalam model regresi yang diteliti.

Tabel 4

Hasil Uji Multikolinieritas

\begin{tabular}{|l|c|c|}
\hline \multirow{2}{*}{ Model } & \multicolumn{2}{|c|}{ Collinearity Statistics } \\
\cline { 2 - 3 } & Tolerance & VIF \\
\hline Kompetensi aparat pengelola dana desa $\left(\mathrm{X}_{1}\right)$ & 0,824 & 1,214 \\
Komitmen organisasi pemerintah desa $\left(\mathrm{X}_{2}\right)$ & 0,784 & 1,275 \\
Partisipasi masyarakat $\left(\mathrm{X}_{3}\right)$ & 0,741 & 1,349 \\
\hline
\end{tabular}

Sumber: Hasil olahan SPSS, 2017

Uji heteroskedastisitas. Nilai signifikansi dari semua variabel independen lebih besar 0,05 . Hal ini berarti bahwa tidak terjadi heteroskedastisitas.

Tabel 5

Hasil Uji Heteroskedastisitas

\begin{tabular}{|l|r|r|r|r|r|}
\hline \multirow{2}{*}{ Model } & \multicolumn{2}{|c|}{$\begin{array}{c}\text { Unstandardized } \\
\text { Coefficients }\end{array}$} & $\begin{array}{c}\text { Standardized } \\
\text { Coefficients }\end{array}$ & \multirow{2}{*}{$\mathrm{t}$} & \multirow{2}{*}{ Sig. } \\
\cline { 2 - 5 } & \multicolumn{1}{|c|}{ B } & Std. Error & \multicolumn{1}{c|}{ Beta } & & \\
\hline Konstanta & 0,413 & 0,155 & & 2,660 & 0,009 \\
Kompetensi Aparat Pengelola Dana Desa $\left(\mathrm{X}_{1}\right)$ & $-0,039$ & 0,023 & $-0,174$ & $-1,735$ & 0,085 \\
Komitmen Organisasi Pemerintah Desa $\left(\mathrm{X}_{2}\right)$ & 0,017 & 0,018 & 0,095 & 0,926 & 0,356 \\
Partisipasi Masyarakat $\left(\mathrm{X}_{3}\right)$ & $-0,017$ & 0,019 & $-0,095$ & $-0,900$ & 0,370 \\
\hline
\end{tabular}

Sumber: Hasil olahan SPSS, 2017 
Hasil Analisis Regresi Berganda. Hasil pengujian regresi berganda adalah sebagai berikut:

$$
Y=-0,713+0,527 X_{1}+0,426 X_{2}+0,230 X_{3}+e
$$

Ringkasan hasil analisis regresi berganda dapat dilihat pada Tabel 6.

Tabel 6

Ringkasan Hasil Analisis Regresi Berganda

\begin{tabular}{|l|c|c|c|}
\hline \multicolumn{1}{|c|}{ Nama Variabel } & Beta & $\mathrm{t}_{\text {hitung }}$ & Sig. \\
\hline Konstanta & $-0,713$ & $-2,328$ & 0,022 \\
\hline Kompetensi Aparat Pengelola Dana Desa $\left(\mathrm{X}_{1}\right)$ & 0,527 & 11,754 & 0,000 \\
\hline Komitmen Organisasi Pemerintah Desa $\left(\mathrm{X}_{2}\right)$ & 0,426 & 11,811 & 0,000 \\
\hline Partisipasi Masyarakat $\left(\mathrm{X}_{3}\right)$ & 0,230 & 6,219 & 0,000 \\
\hline
\end{tabular}

Koefisien Determinasi $\left(\mathbf{R}^{2}\right)$. Nilai $\mathbf{R}$ square sebesar 0,751 . Hal ini berarti bahwa variabel independen yakni kompetensi aparat pengelola dana desa, komitmen organisasi pemerintah desa, dan partisipasi masyarakat menjelaskan $75,1 \%$ variabel dependen yakni akuntabilitas pengelolaan dana desa. Sisanya sebesar $24,9 \%$ dijelaskan oleh variabel lain yang tidak diteliti.

\section{Uji Hipotesis 1: Pengaruh kompetensi aparat pengelola dana desa terhadap akuntabilitas pengelolaan dana desa}

Hasil pengujian Hipotesis pertama $\left(\mathrm{H}_{1}\right)$ yakni pengaruh kompetensi aparat pengelola dana desa terhadap akuntabilitas pengelolaan dana desa menunjukkan nilai $t_{\text {hitung }}>t_{\text {tabel }}(11,754>1,98063)$. Nilai koefisien regresi sebesar 0,527. Tingkat signifikansi sebesar 0,000 ( $\mathrm{p}$ value $<0,05)$. Hal ini menunjukkan kompetensi aparat pengelola dana desa berpengaruh secara positif dan signifikan terhadap akuntabilitas pengelolaan dana desa. Hasil pengujian ini sesuai dengan Stewardship theory (Davis et al, 1997:24). Stewardship theory merupakan salah satu cabang psikologi dan sosiologi dan didesain untuk peneliti menguji kondisi dimana eksekutif sebagai pengelola yang termotivasi untuk melakukan yang terbaik terhadap kepentingan utama organisasi. Dalam stewardship theory dijelaskan bahwa eksekutif sebagai pengelola memiliki peran dalam rangka pencapaian tujuan organisasi. Eksekutif sebagai pengelola dapat dijabarkan kedalam lingkup pengelolaan dana desa. Pemerintah desa sebagai eksekutif/ pelaksana/pengelola/penanggungjawab. Teori akuntabilitas menurut Frink dan Klimoski (2004:3) yang menyatakan bahwa akuntabilitas cenderung berputar pada dua tema tertentu. Tema pertama, menyangkut konteks, yaitu siapa dan apa yang terlibat dalam situasi tertentu. Tema kedua melibatkan pengertian tentang kegiatan evaluasi dan umpan balik dalam beberapa bentuk.

Hasil penelitian ini selaras dengan penelitian sebelumnya oleh Subroto (2009). Hasil penelitiannya mengemukakan bahwa rendahnya kompetensi sumber daya manusia aparat pemerintah desa merupakan faktor penghambat pengelolaan Alokasi Dana Desa yang akuntabel. Rendahnya kompetensi sumber daya manusia serta monitoring dan evaluasi yang kurang efektif mengakibatkan adanya ketidaksesuaian dalam pengelolaan Alokasi Dana Desa. Akibatnya pertanggungjawaban pengelolaan Alokasi Dana Desa belum mencerminkan pengelolaan yang akuntabel. Hasil penelitian Fajri (2015), Irma (2015), dan Makalalag (2017) menunjukkan bahwa pengelolaan keuangan desa (Alokasi Dana Desa dan dana desa) masih mengalami kendala. Akibatnya pertanggungjawaban keuangan desa belum memenuhi asas akuntabilitas. Kendala yang dihadapi oleh pemerintah desa disebabkan lemahnya kapasitas sumber daya manusia pemerintah desa itu sendiri. Dalam melaksanakan pengelolaan dana desa sebagai akibat adanya desentralisasi fiskal yang diserahkan oleh pemerintah pusat kepada pemerintah daerah dan pemerintah daerah kepada pemerintah desa dibutuhkan kesiapan-kesiapan. Salah satu aspek yang perlu dipersiapkan adalah sumber daya manusia (Ferina, 2016). Peningkatan sumber daya manusia di desa dapat dilakukan oleh pemerintah pusat maupun pemerintah daerah. Antara lain melalui sosialisasi, monitoring, evaluasi dan pengawasan guna mendukung terwujudnya masyarakat yang sejahtera dan mandiri (Dewi, 2016). 


\section{Uji Hipotesis 2 : Pengaruh komitmen organisasi pemerintah desa terhadap akuntabilitas pengelolaan dana desa}

Hasil pengujian Hipotesis kedua $\left(\mathrm{H}_{2}\right)$ yakni pengaruh komitmen organisasi pemerintah desa terhadap akuntabilitas pengelolaan dana desa menunjukkan nilai $t_{\text {hitung }}>t_{\text {tabel }}(11,811>1,98063)$. Nilai koefisien regresi sebesar 0,426. Tingkat signifikansi sebesar 0,000 ( $\mathrm{p}$ value $<0,05$ ). Hal ini menunjukkan komitmen organisasi pemerintah desa berpengaruh secara positif dan signifikan terhadap akuntabilitas pengelolaan dana desa. Hasil pengujian ini selaras dengan konsep akuntabilitas yang dikembangkan oleh Cavoukian et al. Cavoukian et al (2010:409) mengemukakan terdapat lima elemen penting dari akuntabilitas adalah: (1). Komitmen organisasi terhadap akuntabilitas dan penerapan kebijakan internal yang konsisten dengan kriteria eksternal, (2). Mekanisme untuk menerapkan kebijakan privasi, termasuk alat, pelatihan, dan pendidikan, (3). Sistem untuk pemeriksaan pengawasan dan penjaminan internal dan eksternal, (4). Transparansi dan mekanisme untuk partisipasi individu, dan (5). Sarana untuk remediasi dan penegakan eksternal. Untuk memaksimalkan pencapaian tujuan organisasi, komitmen orang-orang dalam organisasi menjadi penting. Goal theory (teori penetapan tuujuan) menyatakan bahwa perilaku seseorang individu diatur oleh ide (pemikiran) dan niat seseorang. Sasaran dapat dipandang sebagai tujuan/tingkat kinerja yang ingin dicapai oleh individu. Jika seorang individu komit dengan sasaran tertentu, maka hal ini akan mempengaruhi tindakannya dan mempengaruhi konsekuensi kinerjanya (Suartana, 2010:181). Karyawan yang memiliki komitmen organisasi ditandai dengan adanya keyakinan kuat terhadap nilai dan tujuan organisasi, bersedia meningkatkan upaya untuk kepentingan organisasi dan memiliki keinginan yang kuat untuk tetap berada dalam organisasi (Salleh, et al, 2013:122). Selanjutnya Cullen, et al (2003:127) mengklaim bahwa komitmen organisasi berhubungan dengan fenomena organisasi seperti perilaku kewarganegaraan, prestasi dan produktivitas. Adanya komitmen organisasi akan mempengaruhi produktivitas karena karyawan bersedia untuk bekerja keras (Riketta, 2002:257).

Hasil pengujian ini selaras dengan beberapa penelitian-penelitian sebelumnya. Mamelo (2016), Ferina (2016), dan Fajri (2015) yang menyatakan bahwa dibutuhkan kesiapan pemerintah desa dalam pelaksanaan pengelolaan dana desa. Salah satu yang perlu dipersiapkan pemerintah desa adalah komitmen. Adanya komitmen organisasi diharapkan dapat mendukung pengelolaan dana desa sehingga mampu melaksanakan program kegiatan dengan baik. Keberhasilan pengelolaan dana desa secara akuntabel dilaksanakan oleh pemerintah sebagai wujud komitmen pemerintah desa dalam penyelenggaraan pengelolaan keuangan desa khususnya ADD. Zeyn (2011) dalam penelitiannya menunjukkan bahwa komitmen organisasi berpengaruh terhadap akuntabilitas keuangan. komitmen organisasi yang tinggi berpengaruh terhadap kinerja pemerintah daerah. Komitmen organisasi merupakan alat psikologis dalam menjalankan organisasinya untuk pencapaian sasaran yang diharapkan. Semakin baik komitmen organisasi akan mendorong keberhasilan akuntabilitas publik termasuk akuntabilitas keuangan.

\section{Uji Hipotesis 3 : Pengaruh partisipasi masyarakat terhadap akuntabilitas pengelolaan dana desa}

Hasil pengujian Hipotesis ketiga $\left(\mathrm{H}_{3}\right)$ yakni pengaruh partisipasi masyarakat terhadap akuntabilitas pengelolaan dana desa menunjukkan nilai $t_{\text {hitung }}>t_{\text {tabel }}(6,219>1,98063)$. Nilai koefisien regresi sebesar 0,230. Tingkat signifikansi sebesar 0,000 ( $\mathrm{p}$ value $<0,05$ ). Hal ini menunjukkan partisipasi masyarakat berpengaruh secara positif dan signifikan terhadap akuntabilitas pengelolaan dana desa. Hasil pengujian ini selaras dengan konsep akuntabilitas menurut Agrawal dan Ribot (1999:477) yang mengatakan bahwa semua model akuntabilitas adalah bersifat hubungan. Pada dasarnya terdapat aktor (pemerintah) dan konstituen (masyarakat). Agar pemerintah tidak semenamena menggunakan kekuasaannya, maka masyarakat seharusnya datang meminta pertanggungjawaban pemerintah. Sehingga pelaksanaan desentralisasi akan lebih akuntabel. Crook dan Sverrisson dalam Devas dan Grant (2003:309) Akuntabilitas dapat diperkuat melalui peningkatan partisipasi masyarakat. Sebagai kunci untuk meningkatkan responsivitas pemerintah daerah terhadap masyarakat miskin, dan untuk membuat pembangunan lebih berpihak pada orang miskin. Sebagai mekanisme dalam pertanggungjawaban, partisipasi dilakukan mulai dari evaluasi sampai pelaporan (Ebrahim, 2003:818). Seperti di Los Angeles, partisipasi merupakan cara untuk meningkatkan akuntabilitas sebagai tanggapan yang muncul terhadap tingginya ketidakpercayaan masyarakat terhadap pemerintah. Banyak warga yang menyalahkan pejabat dalam pengambilan keputusan. Studi kasus dari Amerika Serikat dan Korea Selatan menunjukkan bahwa partisipasi warga dapat menyebabkan tata pemerintahan yang lebih baik, karena jarak yang lebih dekat antara pemerintah dan 
warga masyarakat dapat membuat pejabat publik dan pemerintah lebih bertanggung jawab (Kim dan Schachter, 2013:462).

Hasil pengujian ini selaras dengan penelitian Zeyn (2011) bahwa peran masyarakat untuk ikut berpartisipasi dalam perencanaan, pelaksanaan, pengendalian dan pengawasan pembangunan dapat meningkatkan kinerja pemerintah secara efektif, efisien, transparan, dan akuntabel. Rahmanurrasjid (2008:6) mengemukakan hasil penelitiannya, yaitu akuntabilitas dan transparansi dalam pertanggungjawaban pemerintah daerah bisa terwujud dengan adanya partisipasi aktif dari masyarakat. Penelitian yang selaras dengan penelitian ini adalah oleh Mamelo (2016, Karimah (2014), Fajri (2015), Riyanto (2015), Makalalag (2017), Arifiyanto (2017), dan Aziz (2016)

\section{Kesimpulan dan Saran}

Berdasarkan hasil penelitian dan pembahasan dapat disimpulkan bahwa :

1) Kompetensi aparat pengelola dana desa berpengaruh positif dan signifikan terhadap akuntabilitas pengelolaan dana desa di Kabupaten Gorontalo. Artinya semakin kompeten aparat pengelola dana desa, maka pengelolaan dana desa semakin akuntabel.

2) Komitmen organisasi pemerintah desa berpengaruh positif dan signifikan terhadap akuntabilitas pengelolaan dana desa di Kabupaten Gorontalo. Artinya semakin tinggi komitmen pemerintah desa, maka pengelolaan dana desa semakin akuntabel.

3) Partisipasi masyarakat berpengaruh positif dan signifikan terhadap akuntabilitas pengelolaan dana desa di Kabupaten Gorontalo. Artinya semakin intens partisipasi masyarakat, maka pengelolaan dana desa semakin akuntabel.

Berdasarkan hasil penelitian dan pembahasan serta kesimpulan, maka saran yang dapat diberikan adalah sebagai berikut:

1) Perlu adanya pendampingan secara efektif dan efisien oleh pendamping desa, inspektorat, dan pemerintah daerah dalam hal ini SKPD teknis yaitu Badan Pemberdayaan Masyarakat dan Pemerintah Desa Kabupaten Gorontalo terhadap pengelolaan dana desa yang lebih akuntabel.

2) Perlu adanya lembaga/aparat yang bertugas sebagai Internal Control dalam mengawasi jalannya pelaksananaan pengelolaan dana desa.

3) Pemerintah Daerah perlu mempersiapkan strategi/kebijakan dalam mengimplementasikan Peraturan Pemerintah Nomor 71 Tahun 2010 tentang Standar Akuntansi Pemerintahan Berbasis Akrual bagi entitas Pemerintah Desa di Kabupaten Gorontalo.

4) Pemerintah daerah bersama pemerintah desa perlu mensosialisasikan pentingnya keterlibatan masyarakat dalam proses pengelolaan dana desa.

\section{Daftar Pustaka}

Agrawal, Arun., dan Ribot, Jesse C. 1999. Accountability in Decentralization A Framework With South Asian and West African Cases. The Journal of Developing Areas. Vol.33, Page 473-502.

Anwar, Misbahul dan Bambang Jatmiko. 2012. Kontribusi dan Peran Pengelolaan Keuangan Desa untuk Mewujudkan Anggaran Pendapatan dan Belanja Desa yang Transparan dan Akuntabel (Survey pada Perangkat Desa di Kecamatan Ngalik, Sleman, Yogyakarta). Jurnal Akmenika. Vol.11. Hal. 387-410

Arifiyanto, Dwi Febri., dan Kurrohman, Taufik. 2017. Akuntabilitas Pengelolaan Alokasi Dana Desa di Kabupaten Jember. Jurnal Riset Akuntansi dan Keuangan. Vol.2, No.3, hal.481-493.

Aziz, Nyimas Latifah Letty. 2016. Otonomi Desa dan Efektivitas Dana Desa. Jurnal Penelitian Politik. Vol.13, No.2 Hal. 193-211.

Behnam, Michael., dan MacLean, Tommy L. 2011. Where Is The Accountability in International Accountability Standards?: A Decoupling Perspective. Business Ethics Quarterly. Vol.21 No.1, page 47-72.

Bicu, YS. 2013. Kamus Bahasa Indonesia. Jakarta: Citra Harta Prima.

Brown, L David., dan Moore, Mark H. 2001. Accountability, Strategy, and International NonGovernmental Organizations. The Houser Center for Nonprofit Organizations The Kennedy School of Government Harvard University. Working Paper No.7.

Cavoukian, Ann., Taylor, Scott., dan Abrams, Martia E. 2010. Privacy by Design: Essential for Organizational Accountability and Strong Business Practices. Vol.3, Page 405-413.

Cullen, J. F., Parboteeah, K. P., dan Victor, B. 2003. The Effects of Ethical Climates on Organizational Commitment. A Two Study Analysis. Journal of Business Ethics, Vol. 46, No.2. Page 127-141. 
Davis, James H., Schoorman, F David., dan Donaldson, Lex. 1997. Toward a Stewardship Theory of Management. Academy of Management Review. Vol.22, No.1, Page 20-47.

Devas, Nick., dan Grant, Ursula. 2003. Local Governent Decision Making-Citizen Participation and Local Accountability: Some Evidence From Kenya and Uganda. Public Administration and Developmen. Vol.23, Page 307-306.

Dewi, Retno Astuti. 2016. Faktor-Faktor yang Berpengaruh terhadap Kinerja Keuangan Pemerintah Desa Pasca Penerapan Undang-Undang Nomor 6 Tahun 2014. Jurnal Akuntansi Aktual. Vol.3, No. 6 hal. 311-327.

Ebrahim, Alnoor. 2003. Accountability In Practice: Mechanisms for NGO's. World Development. Vol.31, No.5, page 813-829.

Edison, Emron., Yohny Anwar., dan Imas Komariyah. 2016. Manajemen Sumber Daya Manusia, Bandung: CV. Alfabeta.

Fajri, Rahmi. 2015. Akuntabilitas Pemerintah Desa pada Pengelolaan Alokasi Dana Desa (ADD) (Studi pada Kantor Desa Ketindan, Kecamatan Lawang, Kabupaten Malang). Jurnal Administrasi Publik (JAP). Vol.3, No.7, Hal.1099-1104.

Ferina, Ika Sasti. 2016. Tinjauan Kesiapan Pemerintah Desa dalam Implementasi Peraturan Menteri Dalam Negeri Nomor 113 tentang Pengelolaan Keuangan Desa (Studi Kasus pada Pemerintah Desa di Kabupaten Ogan Hir). Jurnal Manajemen dan Bisnis Sriwijaya. Vol.14, No.3. Hal.321-336.

Francis, Paul., dan James, Robert. 2003. Balancing Rural Poverty Reduction and Citizen Participation: The Contradictions of Uganda's Decentralization Program. Worl Development. Vol.31, No.2, page 325-337.

Frinki, Dwight D., dan Klimoski, Richard J. 2004. Advancing Accountability Theory and Practice: Intorduction to The Human Resource Management Review Special Edition. Human Resource Management Review. Vol.14, Page 1-17.

Heller, K., Price, R.H., Reinharz, S., Riger, S., dan Wandersman, A. 1984. Psychology and Community Change: Challenges of the future (2nd ed.). Homewood, Il: Dorsey .

Irma, Ade. 2015. Akuntabilitas Pengelolaan Alokasi Dana Desa (ADD) di Kecamatan Dolo Selatan Kabupaten Sigi. e-Jurnal Katalogis. Vol.3, No.1, Hal.121-137.

Karimah, Faizatul. 2014. Pengelolaan Alokasi Dana Desa dalam Pemberdayaan Masyarakat (Studi pada Desa Deket Kulon Kecamatan Deket Kabupaten Lamongan. Jurnal Administrasi Publik (JAP). Vol. 2. No. 4. Hal.597-602

Kementerian Desa, Pembangunan Daerah Tertinggal, dan Transmigrasi. 2015. Indeks Desa Membangun 2015. Jakarta: Kementerian Desa, Pembangunan Daerah Tertinggal, dan Transmigrasi.

Kementerian Keuangan 2016. Kebijakan Pengalokasian dan Penyaluran Dana Desa Tahun 2017. Disampaikan pada Workshop Penyusunan Rancangan Peraturan Kepala Daerah mengenai Tata Cara Perhitungan, Pembagian dan Penetapan Rincian Dana Desa TA 2017. Redtop Hotel and Convention Center. 21-24 November 2016.

Kim, Soojin., dan Schachter, Hindy Lauer. 2013. Citizen Participation in The Budget Process and Local Government Accountability. Case Studies of Organizational Learning from the United States and South Korea. Public Performance and Management Review. Vol.36, No.3, Page 456-471.

Mahmudi, 2011. Akuntansi Sektor Publik. Cetakan pertama. Yogyakarta: UII Press.

Makalalag, Astri Juainita. 2017. Akuntabilitas Pengelolaan Dana Desa di Kecamatan Kotamobagu Selatan Kota Kotamobagu. Jurnal Riset Akuntansi dan Auditing "Goodwill”. Vol. 8, No. 1. Hal.149-158.

Mamelo, Gresly Yunius Rainal. 2016. Analisis Pelaksanaan dan Penatausahaan Dana Desa pada Desa-Desa dalam Wilayah Kecamatan Kotamobagu Timur Kota Kotamobagu. Jurnal Riset Akuntansi dan Auditing "Goodwill”. Vol. 7, No. 2. Hal.148-159.

Nadir, Sakinah. 2013. Otonomi Daerah dan Desentralisasi Desa: Menuju Pemberdayaan Masyarakat. Jurnal Politik Profetik. Vol.1, No.1. Hal.1-21.

Nordiawan, Dedi. 2006. Akuntansi Sektor Publik. Jakarta: Salemba Empat .

Porter, LymanW., Steers, Richard M,. Mowday, Richard T., dan Boulian, Paul V. 1974. Organizational Commitment, Job Satisfaction, and Turnover Among Psychiatric Technicians. Journal of Applled Psychology. Vol.59, Page 603-609. 
Rahmanurrasjid, Amin. 2008. Akuntabilitas dan Transparansi dalam Pertanggungjawaban Pemerintah Daerah untuk Mewujudkan Pemerintahan yang Baik di Daerah. Tesis. Program Pasca Sarjana Universitas Diponegoro.

Riketta, M. 2002. Attitudinal Organizational Commitment and Job Performance: A Meta-Analysis. Journal of Organizational Behavior. Vol.23, No.3, Page 257-266.

Riyanto, Teguh. 2015. Akuntabilitas Finansial dalam Pengelolaan Alokasi Dana Desa (ADD) di Kantor Desa Perangat Selatan Kecamatan Marangkayu Kabupaten Kutai Kartanegara. eJournal Administrasi Negara. Vol. 3, No.1. Hal.119-130.

Roberts, Nancy. 2002. Keeping Public Officials Accountable Through Dialogue: Resolving The Accountability Paradox. Public Administration Review. Vol.6, No.6, page 658-669.

Salleh, Munir., Amin, Aziz., Muda, Shalahudin., dan Abdul Halim, Muhammad Abi Sofian. 2013. Fairness of Performance Appraisal and Organizational Commitment. Asian Social Science. Vol.9. No.2, Page 121-128.

Suartana, I Wayan. 2010. Akuntansi Keperilakuan: Teori dan Implementasi. Edisi 1. Yogyakarta: Andi Offset.

Subroto, Agus. 2009. Akuntabilitas Pengelolaan Dana Desa (Studi Kasus Pengelolaan Alokasi Dana Desa di Desa-Desa dalam Wilayah Kecamatan Tlogomulyo Kabupaten Temanggung Tahun 2008). Tesis Program Studi Magister Sains Akuntansi Program Pasca Sarjana Universitas Diponegoro.

Sujarweni, V. Wiratna. 2015. Akuntansi Desa: Panduan Tata Kelola Keuangan Desa. Yogyakarta: Pustaka Baru Press.

Widodo, Isto. 2017. Dana Desa dan Demokrasi Dalam Perspektif Desentralisasi Fiskal. Politik Indonesia. Indonesian Political Science Review. Vol.2, No.1, Hal.66-86.

Zeyn, Elvira. 2011. Pengaruh Good Governance dan Standar Akuntansi Pemerintahan terhadap Akuntabilitas Keuangan dengan Komitmen Organisasi sebagai Pemoderasi. Jurnal Reviu Akuntansi dan Keuangan. Vol.1, No.1, Hal.21-37. 